\title{
Natural radionuclides in lichens, mosses and ferns in a thermal power plant and in an adjacent coal mine area in southern Brazil
}

\author{
Juliana Aparecida Galhardi a, *, Rafael García-Tenorio b, Inmaculada Díaz Francés b, \\ Daniel Marcos Bonotto ${ }^{a}$, Marcelo Pinto Marcelli ${ }^{c}$ \\ ${ }^{a}$ UNESP, Rio Claro, São Paulo, Brazil \\ ${ }^{\mathrm{b}}$ Universidad de Sevilla, Sevilla, Spain \\ c Instituto de Botânica, São Paulo, Brazil
}

\section{A R T I C L E I N F O}

\section{Article history:}

Received 11 May 2016

Received in revised form

8 November 2016

Accepted 9 November 2016

Available online 18 November 2016

\section{Keywords:}

Bio-monitoring

Uranium

Thorium

Polonium

Coal-industry

Southern Brazil

\begin{abstract}
A B $S T R$ A C $T$
The radio-elements ${ }^{234} \mathrm{U},{ }^{235} \mathrm{U},{ }^{238} \mathrm{U},{ }^{230} \mathrm{Th},{ }^{232} \mathrm{Th}$ and ${ }^{210} \mathrm{Po}$ were characterized in lichens, mosses and ferns species sampled in an adjacent coal mine area at Figueira City, Paraná State, Brazil, due to their importance for the assessment of human exposure related to the natural radioactivity. The coal is geologically associated with a uranium deposit and has been used as a fossil fuel in a thermal power plant in the city. Samples were initially prepared at LABIDRO (Isotopes and Hydrochemistry Laboratory), UNESP, Rio Claro (SP), Brazil. Then, alpha-spectrometry after several radiochemical steps was used at the Applied Nuclear Physics Laboratories, University of Seville, Seville, Spain, for measuring the activity concentration of the radionuclides. It was ${ }^{210}$ Po the radionuclide that most bio-accumulates in the organisms, reaching the highest levels in mosses. The ferns species were less sensitive as bio-monitor than the mosses and lichens, considering polonium in relation to other radionuclides. Fruticose lichens exhibited lower polonium content than the foliose lichens sampled in the same site. Besides biological features, environmental characteristics also modify the radio-elements absorption by lichens and mosses like the type of vegetation covering these organisms, their substrate, the prevailing wind direction, elevation and climatic conditions. Only ${ }^{210} \mathrm{Po}$ and ${ }^{238} \mathrm{U}$ correlated in ferns and in soil and rock materials, being particulate emissions from the coal-fired power plant the most probable U-source in the region. Thus, the biomonitors used were able to detect atmospheric contamination by the radionuclides monitored.
\end{abstract}

() 2016 Elsevier Ltd. All rights reserved.

\section{Introduction}

Radionuclides evaluation in areas affected by the coal industry is important for the assessment of human exposure to the natural radioactivity. The main concern about the air pollution associated with coal mining and coal-fired thermal power plants comes from the fact that fossil fuels may contain natural levels of toxic and radioactive elements (UNSCEAR, 2010) that can vary according to some chemical, physic-chemical and biological factors (Giblin et al., 1981).

UNSCEAR (2010) reported coal analysis in fifteen countries, giving a value of $20 \mathrm{Bqkg}^{-1}$ for the average activity concentrations of

\footnotetext{
* Corresponding author. UNESP, Avenida 24-A, No. 1515, 13506-900, CP 178, Rio Claro, São Paulo, Brazil.

E-mail address: julianagalhardi@yahoo.com.br (J.A. Galhardi).
}

${ }^{238} \mathrm{U}$ and ${ }^{232} \mathrm{Th}$. However, radionuclides can be found in greater concentrations like in coal from Rio Bonito Formation, Figueira city, Brazil, where Flues et al. (2006) found ${ }^{238} \mathrm{U}$ and ${ }^{232} \mathrm{Th}$ activity concentrations of $813-2609 \mathrm{Bqkg}^{-1}$ and $22-40 \mathrm{Bqkg}^{-1}$, respectively.

The natural decay series initiating with ${ }^{238} \mathrm{U},{ }^{235} \mathrm{U}$ and ${ }^{232} \mathrm{Th}$ give rise to a variety of radioactive products, including ${ }^{222} \mathrm{Rn}$ and ${ }^{210} \mathrm{Po}$. Although the main uranium carrier is water, dust and atmospheric particulate matter can act as alternative routes to this radioelement dispersion (Mkandawire, 2013). Human activities such as emissions from fertilizer industries, motor vehicles, coal mining and burning fossil fuels in thermal power plants can artificially increase the activity concentration of these radionuclides in the atmosphere (Flues et al., 2006; Papastefanou, 2010; Sert et al., 2011; Zhang et al., 2016).

In coal-fired power plants, a portion of the ashes and gases is released into the atmosphere (Baxter, 1993) and based on the property of being easily volatilized at low temperatures 
(approximately $70^{\circ} \mathrm{C}$ ), polonium plays an important role in the investigation of atmosphere pollution. The amount of natural radionuclides emitted to the atmosphere from a thermal power plant depends on some factors, such as their concentrations in coal, the content of ash in coal, the temperature of the combustion and the emission control efficiency (Delfanti et al., 1999; Sert et al., 2011). Tailing piles containing wastes originated during the mining activities also comprises additional sources of radionuclides to the environment (Fungaro and Izidoro, 2006). For example, due to the long half-life of ${ }^{230} \mathrm{Th}$, the precursor of ${ }^{226} \mathrm{Ra}$, tailing piles represent long sources of this radionuclide (Landa, 2003). In addition, effluents from coal mining may contain common contaminants of metallic minerals mining and also radioactive elements, such as ${ }^{226} \mathrm{Ra},{ }^{210} \mathrm{~Pb}$ and ${ }^{238} \mathrm{U}$ (USEPA, 1995), which can be released into natural waters in accelerated rate due to the oxidation of sulfide minerals by natural processes in rocks that gives rises to acid mine drainage (Nordstrom, 2009).

In the context of environmental pollution related to coal industry, bio-indicators/bio-monitors, such as lichens and mosses, have been used to indicate the pollution levels in air quality studies (Markert, 2007) and to identify radionuclides, toxic metals and organic compounds in atmospheric particulate matter from natural or artificial sources (Beckett et al., 1982; Steinnes and Njastad, 1993; Bargagli et al., 1995; Berg et al., 1995; Nifontova, 1995; Steinnes, 1995; Delfanti et al., 1999; Heinrich et al., 1999; Fernandez et al., 2000 . Genoni et al., 2000; Jeran and Jacimovic, 2001; Conti and Cecchetti, 2001; Figueira et al., 2002; Kirchner and Daillant, 2002; Di Lella et al., 2003; Loppi et al., 2003; Tsikritzis et al., 2003; Ugur et al., 2004; Golubev et al., 2005; Belivermis and Çotuk, 2010; Sert et al., 2011; Van Der Wat and Forbes, 2015).

Lichens, or lichenized fungi, are formed by the symbiosis between a fungus and one or more algae or cyanobacteria (Conti and Cecchetti, 2001; Villarouco et al., 2007). This symbiotic association forms a certain structure (thallus) that has no roots and depends mainly on the atmospheric input of mineral nutrients (Garty et al., 2003). The main mechanism of radionuclides accumulation by lichens is due to the dry or wet deposition and they can accumulate and retain elements in concentrations that exceed their physiological requirements due to their relatively large surface area and slow growth rate (Golubev et al., 2005). Therefore, it has been assumed that the elements absorbed by lichens represent a fraction of the chemical composition of the atmosphere (Di Lella et al., 2003). These features of lichens, combined with their capability to grow in different environmental conditions and to accumulate mineral elements far above their needs, make them one of the greatest bioindicators of air pollution (Garty et al., 2003).

The rhizoid system of mosses allows these organisms to partially absorb the nutrients from soil and transport them to the leaves. However, these organisms generally do not have vascular and root systems to uptake elements from the soil and like the lichens they are strongly dependent of the material deposited through wet and dry deposition. As a result, mosses can also act as efficient air pollution indicators because they absorb chemical particles directly from the atmosphere (Elias et al., 2006) mainly in the leaf, which is the part of the plant that shows the greatest response to environmental variations (Rocha et al., 2014).

Epiphytism corresponds to the growing of plants over others, especially trees, without connection to soil and without parasitism (Dubuisson et al., 2009). Some ferns species are epiphytic, comprising one of the major components of the rainforest biodiversity spreading in the tropics (Mohlenbrock, 2006; Dubuisson et al., 2009). These ferns species cannot live without a host plant because they have no attachment to the ground and grows upon another plant merely for physical support (Mohlenbrock, 2006). This is the case of the specie Microgramma squamulosa (Kaulf.) de la
Sota, which is a neotropical epiphytic fern commonly found in Brazil and in other latinoamerican countries, like Peru, Bolivia, Argentina, Paraguay, and Uruguay.

Microgramma squamulosa (Kaulf.) de la Sota can be found in trees of primary and secondary forests and in isolated trees in urban and rural environments (Rocha et al., 2014). This native species is considered a potential bio-indicator, since some morphological adaptations were found in it in polluted environments, like a decrease in the stomata area to minimize the pollutants uptake by the plant (Alves et al., 2001). Rocha et al. (2014) suggested that controlled studies involving active exposure to pollutants may contribute to increase the knowledge about Microgramma squamulosa (Kaulf.) de la Sota as a potential bioindicator of atmospheric air pollution.

The bio-monitoring can be made passively when the studied species already occur in the investigated site. In areas of extraction, processing and coal burning, the application of the passive biomonitoring method focusing on radioactive elements becomes attractive as the use of bio-indicators offers some advantages when compared to conventional methods for air monitoring. This is because they provide information about continuous accumulation of radioactive elements over the time, whereas the sampling of air, rainwater and the material deposited on the filters and collectors provide instantaneous and prompt information regarding a period corresponding only to the sampling time (Alencar, 2008). For example, many moss species live for $2-5$ years, allowing their application in long-term studies (Sert et al., 2011).

Conventional sampling methods of air and pluvial water may be attractive in the case of toxic metals monitoring, but for uranium, thorium and other radio-elements, it may be more suitable to get information integrated over a longer time period and, according to Leonardo et al. (2011), other advantages associated with biomonitoring are the easy sampling work, less expensive equipment and lower operational and maintenance costs.

Only a few investigations of power plant emissions, airborne pollutants and lichens as biomonitors were performed in tropical zones compared to temperate ones (Garty et al., 2003). Their climatic characteristics, environmental and weathering processes, nutrients recycling and the radionuclides uptake or absorption by living organisms differ significantly (IAEA, 2010). Seed et al. (2013) showed that climate factors can control the lichen distribution and abundance but effects of climatic changes on lichens and mosses species from tropical areas is often unknown, since most of the studies were conducted in the developed countries under temperate climate. According to Carreras et al. (2009), it is essential to hold studies in cities from developing countries and in tropical areas where the socio-demographic-economic characteristics of local population differ considerably from those in developed and temperate countries.

In Brazil, some researchers reported the efficiency of lichens as bioindicators of the air pollution by radionuclides in areas of fertilizer production (Alencar, 2008; Leonardo et al., 2013), affected by a thermoelectric plant (Martins et al., 2008) and close to a lead and tin industries (Leonardo et al., 2011). There isn't any investigation to evaluate the air pollution by radionuclides using lichens, mosses and ferns as bio-indicators in Paraná State, southern Brazil, where there is the third largest coal reserve of the country. Risks associated with the coal industry at Figueira city, Paraná State, may be more critical as the coal horizons are associated with a uranium deposit.

In this context, the objective of this research was to evaluate the absorption of ${ }^{234} \mathrm{U},{ }^{238} \mathrm{U},{ }^{232} \mathrm{Th},{ }^{230} \mathrm{Th}$ and ${ }^{210}$ Po by ferns, lichens and mosses in the coal mining and coal-fired power plant areas at Figueira city, Paraná State, Brazil, as an aid to a better understanding of the radionuclides absorption by ferns, lichens and mosses in tropical areas. 


\section{Materials and methods}

\subsection{Description of the study area}

Figueira city is located in the northeastern of Paraná State in Brazil (Fig. 1). Uranium and coal deposits occur in the area, related to Rio Bonito Formation (Medeiros and Thomaz Filho, 1973). The coal horizons are $0.50-0.65 \mathrm{~m}$ thick and located at 38-75 $\mathrm{m}$ depth (ANEEL, 2011). Chemical analysis indicates a moisture content of $6 \%$, volatile matter of $28.8 \%$, carbon of $32.5 \%$, ash content of $38.7 \%$, sulfur content of $4-12 \%$ and calorific value of $4300 \mathrm{kcal} \mathrm{kg}^{-1}$ (dry weight), allowing to classify the coal as high volatile bituminous (Shuqair, 2002).

Coal is nowadays extracted from an underground pit in operation since 2014. However, coal mining occurs since the 1950s and left underground tunnels, deep changes in the local relief and problems associated with the water and soil quality, mostly associated with the wastes disposal in tailing piles. Coal is pulverized into fly ash and collected by emission control systems in the thermal power plant in operation since 1963. Flues et al. (2006) reported that the coal combustion in the thermal power plant in Figueira city increases the radionuclides concentration in the atmospheric particulate matter by a factor of 5-10 times. Campaner et al. (2014) also found high activity concentrations of ${ }^{238} \mathrm{U},{ }^{226} \mathrm{Ra}$ and ${ }^{210} \mathrm{~Pb}$ in coal, its fly ash and topsoil of the area.

The coal ashes collected from the filters are disposed in a reject dump, which in conjunction with the tailing piles, containing richin-pyrite rejected coal, can be responsible for the increase of soil and groundwater contamination due to the release of toxic and radioactive elements, which in turn might also affect the local biota.

\subsection{Collection and pretreatment of samples}

The species of lichens, fern and mosses were collected in February/2015 in places close to the thermal power plant and the coal mining in Figueira city and in remote sites, with the aid of a spatula and a knife at heights $>1 \mathrm{~m}$ above the ground. The samples were properly packed and sent to the Botanic Institute of São Paulo, Brazil, for treatment and identification. Coal from the underground coal mine $(\mathrm{C} 1, \mathrm{C} 2)$, soil from the area $(\mathrm{S} 1-\mathrm{S} 3)$ and ash samples (A1, A2) from a tailing pile containing solid waste from the thermal power plant were also sampled. Tables 1 and 2 describe the samples collected and Fig. 2 the sampling points location.

In LABIDRO - Isotopes and Hydrochemistry Laboratory, UNESP, Rio Claro, São Paulo, Brazil, the samples were washed with distilled water to remove the residual particulates, oven dried at $60^{\circ} \mathrm{C}$ until constant weight and manually macerated and homogenized, as described by Loppi et al. (2003) and Saiki et al. (2007). Alphaspectrometry was used for measuring the activity concentration of the radionuclides ${ }^{234} \mathrm{U},{ }^{235} \mathrm{U},{ }^{238} \mathrm{U},{ }^{230} \mathrm{Th},{ }^{232} \mathrm{Th}$ and ${ }^{210} \mathrm{Po}$. The measurements were performed at the Applied Nuclear Physics Laboratories, University of Seville, Seville, Spain.

\subsection{Extraction by UTEVA resin and alpha spectrometry}

A fraction of the dry sample (Table 1 ) of each species was digested in an open system with $50 \mathrm{~mL}$ of $\mathrm{HNO}_{3} 8 \mathrm{M}$, after adding the tracer solution containing ${ }^{209} \mathrm{Po}^{228}{ }^{22} \mathrm{Th}-{ }^{232} \mathrm{U}$. The total solution was heated to $60{ }^{\circ} \mathrm{C}$ for $8 \mathrm{~h}$ and shaken for $12 \mathrm{~h}$ without heating. After this period, $\mathrm{H}_{2} \mathrm{O}_{2}$ and $\mathrm{HNO} 38 \mathrm{M}$ were gradually added to each sample and they remained heated at $60{ }^{\circ} \mathrm{C}$ for further $8 \mathrm{~h}$. The total

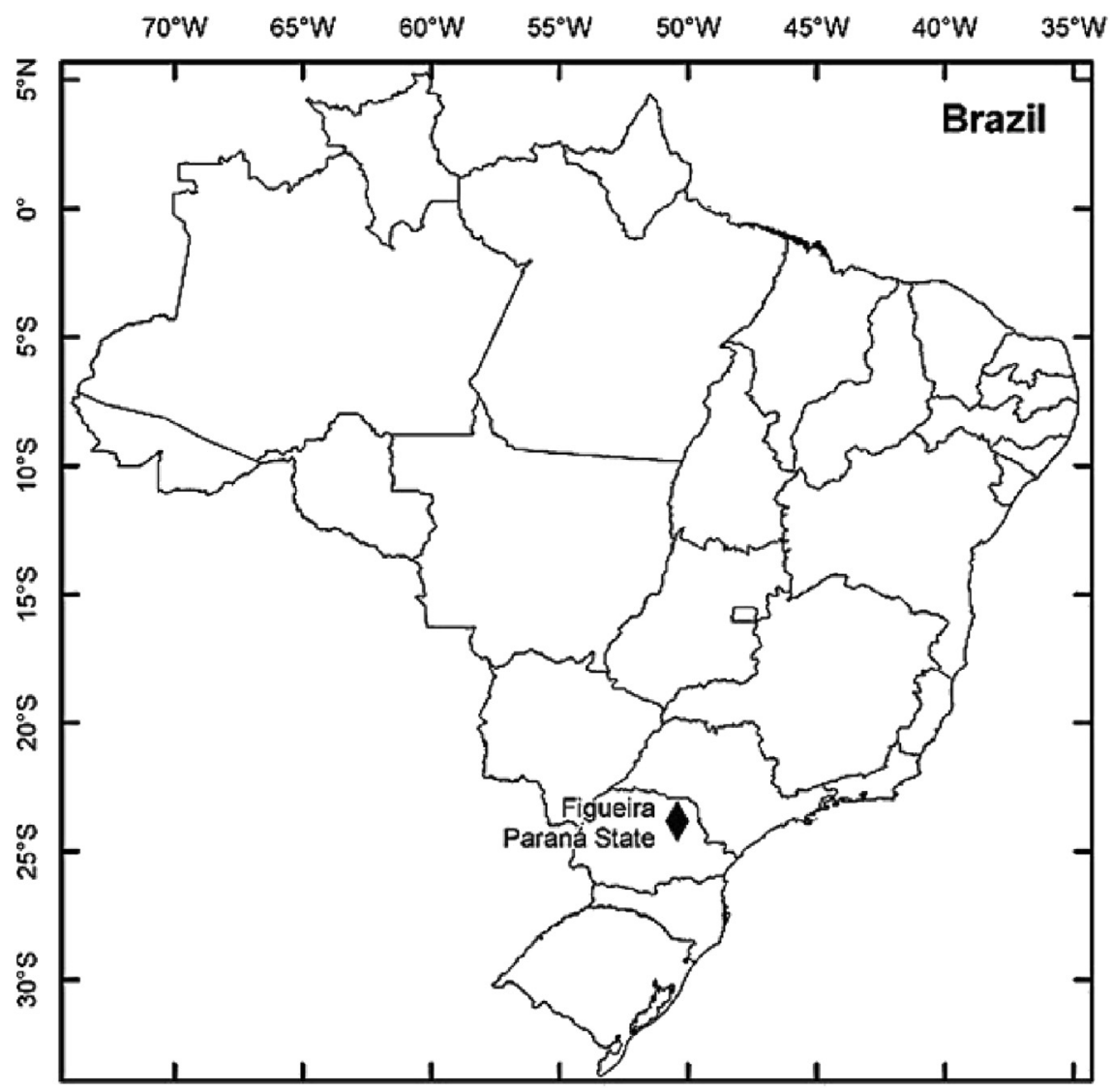

Fig. 1. - Location of the study area. 
Table 1

Ferns, mosses and lichens samples description.

\begin{tabular}{|c|c|c|c|c|c|}
\hline Sample & Specie & Dry weight $(\mathrm{g})$ & Substrate & Long & Lat \\
\hline $\mathrm{F} 1$ & Microgramma squamulosa (Kaulf.) de la Sota & 5.983 & Bark & 555,963 & $7,372,580$ \\
\hline $\mathrm{F} 2$ & Microgramma squamulosa (Kaulf.) de la Sota & 6.005 & Bark & 559,973 & $7,361,343$ \\
\hline F3 & Microgramma squamulosa (Kaulf.) de la Sota & 3.726 & Bark & 559,540 & $7,365,236$ \\
\hline F4 & Microgramma squamulosa (Kaulf.) de la Sota & 6.586 & Bark & 559,732 & $7,366,488$ \\
\hline F5 & Microgramma squamulosa (Kaulf.) de la Sota & 4.700 & Bark & 562,214 & $7,362,060$ \\
\hline M1 & Cylindrocolea rhizantha (Mont.) R.M. Schust. & 8.213 & Soil & 558,428 & $7,362,000$ \\
\hline M2 & Cylindrocolea rhizantha (Mont.) R.M. Schust. & 4.590 & Rock & 563,409 & $7,364,063$ \\
\hline M3 & Sematophyllum galipense (Müll. Hal.) Mitt. & 8.602 & Soil & 558,015 & $7,357,491$ \\
\hline M4 & Sematophyllum galipense (Müll. Hal.) Mitt. & 9.343 & Bark & 558,015 & $7,357,491$ \\
\hline L1 & Parmotrema sp. & 0.716 & Bark & 555,963 & $7,372,580$ \\
\hline $\mathrm{L} 2$ & Ramalina peruviana & 1.611 & Bark & 555,963 & $7,372,580$ \\
\hline L3 & Usnea sp & 4.976 & Bark & 555,963 & $7,372,580$ \\
\hline L4 & Parmotrema tinctorum & 1.980 & Bark & 555,963 & $7,372,580$ \\
\hline L5 & Parmotrema sancti-angeli & 3.446 & Bark & 555,963 & $7,372,580$ \\
\hline L6 & Parmotrema cf. praesorediosum & 5.014 & Rock & 556,153 & $7,362,002$ \\
\hline L7 & Heterodermia pseudospeciosa & 14.336 & Rock & 556,153 & $7,362,002$ \\
\hline L8 & Canoparmelia crozalsiana & 11.459 & Bark & 559,973 & $7,361,343$ \\
\hline L9 & Parmotrema tinctorum & 2.273 & Bark & 563,409 & $7,364,063$ \\
\hline L10 & Canoparmelia crozalsiana & 2.617 & Bark & 557,770 & $7,366,403$ \\
\hline L11 & Canoparmelia texana & 6.751 & Bark & 559,540 & $7,365,236$ \\
\hline L12 & Canoparmelia crozalsiana & 2.302 & Bark & 559,072 & $7,359,735$ \\
\hline
\end{tabular}

Table 2

Coal, coal ash and soil samples description.

\begin{tabular}{lllll}
\hline Sample & Type & Dry weight $(\mathrm{g})$ & Longitude & Latitude \\
\hline S1 & Soil & 0.610 & 557,172 & $7,370,565$ \\
S2 & Soil & 0.600 & 558,137 & $7,365,862$ \\
S3 & Soil & 0.601 & 559,813 & $7,364,933$ \\
C1 & Coal & 0.500 & - & - \\
C2 & Coal & 0.601 & - & - \\
A1 & Coal ash & 0.597 & - & - \\
A2 & Coal ash & 0.588 & - & - \\
\hline
\end{tabular}

solution once again was shaken without heat for $12 \mathrm{~h}$ and, after the acid digestion, the resulting solution was filtered through a cellulose membrane with porosity of $45 \mu \mathrm{m}$ and the supernatant was evaporated and re-dissolved in $10 \mathrm{~mL}$ of $\mathrm{HNO}_{3} 3 \mathrm{M}$. The volume of the solution was completed with deionized water to $50 \mathrm{~mL}$ and it was added $2 \mathrm{~mL}$ of an iron carrier solution $\left(\mathrm{Fe}^{3+}\right)$ and ammonia, until it reached a $\mathrm{pH}$ around 8.5. At this point, the iron hydroxide precipitation occurs, carrying together $U$, Th and Po. The samples were centrifuged and $10 \mathrm{~mL}$ of $\mathrm{HNO}_{3} 8 \mathrm{M}$ were added to the precipitate.

In the next step, $U$, Th and Po were extracted by liquid-liquid extraction (Mantero et al., 2010; Lehritani et al., 2012). The method consisted of three parts, starting with the Po extraction. They were added $10 \mathrm{~mL}$ of tributyl phosphate (TBP) in a separation funnel to the previously prepared solution. The solution was shaken for $10 \mathrm{~min}$ before the extraction. The procedure was repeated three more times using $\mathrm{HNO}_{3} 8 \mathrm{M}$. In this step, Th and $\mathrm{U}$ were retained in the organic phase, whereas Po was transferred to the aqueous phase.

The second step consisted in Th extraction and $20 \mathrm{~mL}$ of xylene plus $15 \mathrm{~mL}$ of $\mathrm{HCl} 1.5 \mathrm{M}$ were added to the separation funnel. The extraction was repeated two times more with $15 \mathrm{~mL}$ of $\mathrm{HCl} 1.5 \mathrm{M}$. Uranium was in the solution containing the mixture of organic compounds, while Th was eluted. Finally, for U separation, three extractions were conducted, adding $15 \mathrm{~mL}$ of deionized water into the separation funnel for recovering the uranium from TBP into the aqueous phase. The solutions containing $U$, Th and Po were heated to dryness.

The Th isolated fraction contains some impurities of $U$ that could affect the acquisition of the Th data. To remove these impurities it was applied the extraction chromatographic technique with UTEVA resins (Uranium and Tetra-valent Actinides), consisting of a $2 \mathrm{~mL}$ column filled with diamyl-amylphosphonate sorbed onto an inert polymeric support (Amberlite XRAD-7). The UTEVA column was firstly pre-conditioned with $5 \mathrm{~mL}$ of $\mathrm{HNO}_{3} 3 \mathrm{M}$, since Th forms adsorbable complexes in a nitric medium. Then, $5 \mathrm{~mL}$ of $\mathrm{HNO}_{3} 3 \mathrm{M}$ were added to the glass containing the extracted Th and this solution was drained in the column. Such procedure was repeated two more times and the drained volume was discarded. After this, it was added $5 \mathrm{~mL}$ of $\mathrm{HCl} 9 \mathrm{M}$ to the resin to convert the column into chloride form. After draining $20 \mathrm{~mL}$ of $\mathrm{HCl} 5 \mathrm{M}$, Th was eluted as the solution collected was sufficiently purified to allow the Th electrodeposition.

For Po auto-deposition, about $1 \mathrm{~g}$ of ascorbic acid (to avoid iron precipitation) and $50 \mathrm{~mL}$ of $\mathrm{HCl} 1.5 \mathrm{M}$ were added to the beaker containing a copper disc and the Po isolated after its evaporation. After $2 \mathrm{~h}$ of heating $\left(50-60{ }^{\circ} \mathrm{C}\right)$, Po was auto-deposited on the copper disc (Díaz-Francés et al., 2013).

Th and $U$ were electro-deposited in stainless steel discs (Hallstadius, 1984) and the procedure consisted of adding $0.5 \mathrm{~g}$ of $\mathrm{H}_{2} \mathrm{SO}_{4}$ (ultrapure), $5 \mathrm{~mL}$ of deionized water and 2 drops of phenolphthalein to the beakers containing the $U$ and Th previously extracted. The $\mathrm{pH}$ was converted to the turning point using ammonia vapor. The solution was put into the electroplating cell and the $\mathrm{pH}$ was adjusted to approximately 2.4 by the addition of $\mathrm{H}_{2} \mathrm{SO}_{4}, 1 \%$. With a platinum wire acting as the anode, a current of 1.2 A was applied for $1 \mathrm{~h}$ for the $\mathrm{U}$ electro-deposition in the disk. Th electro-deposition was proceeded for $2 \mathrm{~h}$ in a current $1.5 \mathrm{~A}$.

The alpha emissions were measured through a Canberra system using semiconductor PIPS (Passivated Implanted Planar Silicon) detectors, wherein Po, $\mathrm{U}$ and Th alpha particles were counted in different chambers in order to avoid contamination. The system was calibrated with standards of ${ }^{239} \mathrm{Pu},{ }^{242} \mathrm{Pu}$ and ${ }^{241} \mathrm{Am}$ and the Alpha Analyst program was used for processing the spectra. The mean chemical yields for alpha spectrometry were $49 \%, 54 \%$ and $60 \%$, respectively, for uranium, polonium and thorium.

\section{Results and discussion}

Based on data provided by the National Meteorological Institute from Brazil (INMET), the wind velocity between 2009 and 2014 in the area ranged from $0.9 \mathrm{~ms}^{-1}$ (June) to $1.8 \mathrm{~ms}^{-1}$ (January). It 


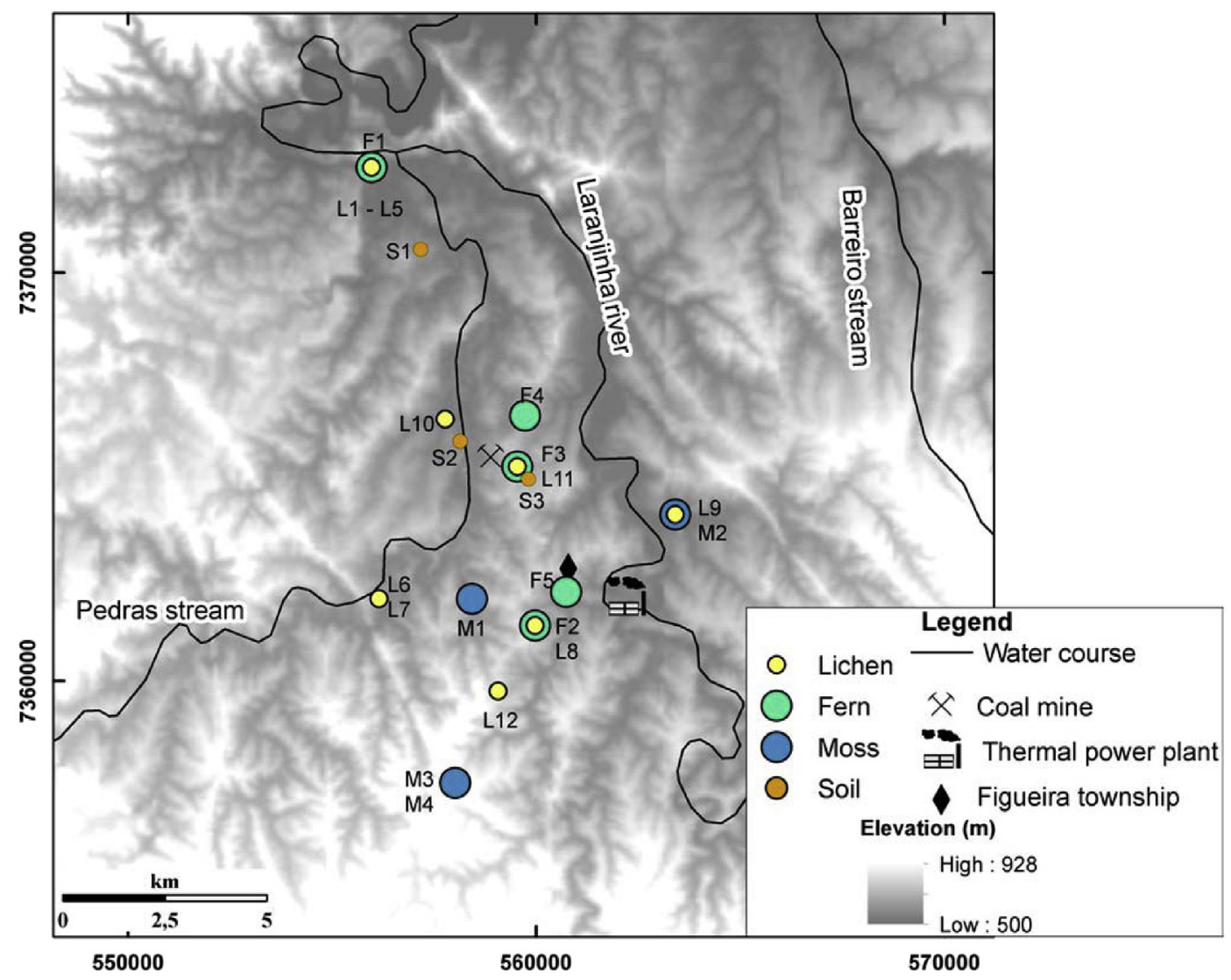

Fig. 2. Location of the sampling points.
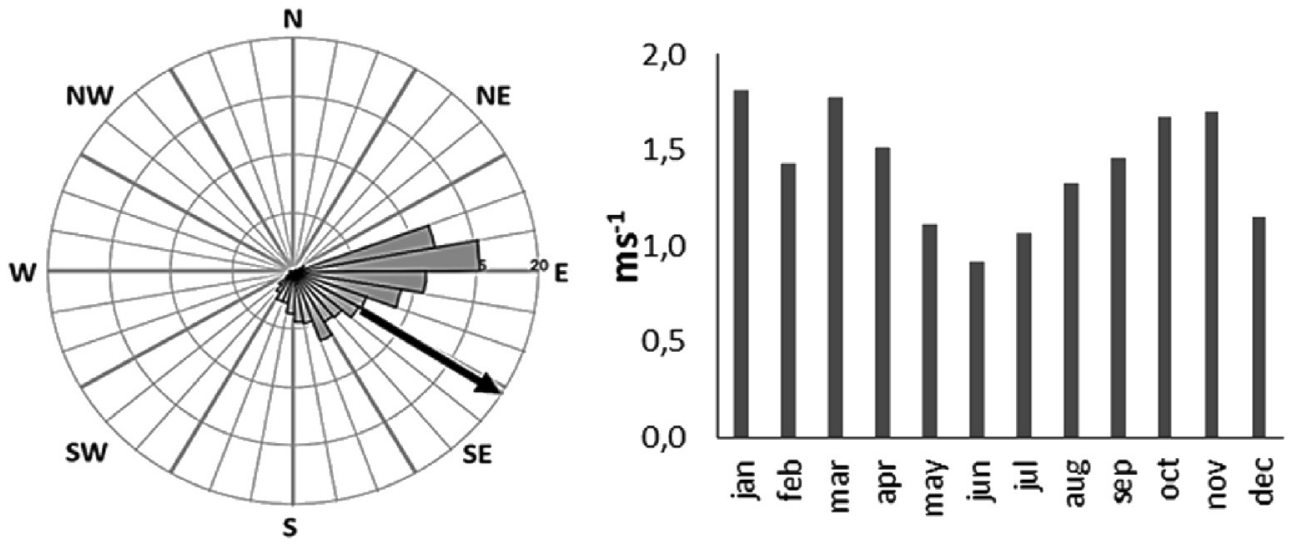

Fig. 3. Wind direction (left) and monthly average of the wind velocity (right) from 2009 to 2014 .

tended to be lower during the dry season (March to August) and the prevailing wind direction was SE-NW (Fig. 3).

Tables 3-5 show the radionuclide data obtained. It is observed that different species sampled at the same location may differ in their accumulation. The ferns absorbed larger amount of ${ }^{210} \mathrm{Po}$, followed by ${ }^{230} \mathrm{Th},{ }^{234} \mathrm{U},{ }^{238} \mathrm{U},{ }^{232} \mathrm{Th}$ and ${ }^{235} \mathrm{U}$. Mosses exhibited higher activity concentrations of ${ }^{210} \mathrm{Po}$, followed by ${ }^{238} \mathrm{U},{ }^{234} \mathrm{U}$, ${ }^{230} \mathrm{Th},{ }^{235} \mathrm{U}$ and ${ }^{232} \mathrm{Th}$, while lichens absorbed more ${ }^{210} \mathrm{Po}$, followed by ${ }^{234} \mathrm{U},{ }^{238} \mathrm{U},{ }^{230} \mathrm{Th},{ }^{232} \mathrm{Th}$ and ${ }^{235} \mathrm{U}$. Mossess exhibited the highest average concentrations for all radionuclides when compared to the lichens and ferns, whereas ${ }^{210}$ Po showed the highest average concentration in the three sample groups.
The ferns species are found frequently in urban and rural areas of the study zone and in environments affected by mining activities. It showed lower ${ }^{210} \mathrm{Po}$ activity concentration than mosses (107-720) $\mathrm{Bqkg}^{-1}$ and lichens (120-616) $\mathrm{Bqkg}^{-1}$, being less sensitive as a biomonitor than the mosses and lichens species in terms of polonium and also for other radionuclides accumulation.

Lichens can be divided into three groups, regarding thallus morphology: fruticose, foliose and crustose lichens (Büdel and Scheidegger, 1996). During the lichens sampling, it was verified that the fruticose species (samples L2 and L3) were less common in the study area, occurring more frequently in remote zones from the mine and the thermal power plant. This group is highly branched 
Table 3

Radionuclides content in ferns, mosses and lichens samples.

\begin{tabular}{|c|c|c|c|c|c|c|c|c|}
\hline Sample & ${ }^{210} \mathrm{Po}\left(\mathrm{Bqkg}^{-1}\right)$ & ${ }^{232} \mathrm{Th}_{\left(\mathrm{Bqkg}^{-1}\right)}$ & ${ }^{230} \mathrm{Th}\left(\mathrm{Bqkg}^{-1}\right)$ & ${ }^{238} \mathrm{U}\left(\mathrm{Bqkg}^{-1}\right)$ & ${ }^{235} \mathrm{U}\left(\mathrm{Bqkg}^{-1}\right)$ & ${ }^{234} \mathrm{U}\left(\mathrm{Bqkg}^{-1}\right)$ & ${ }^{234} U /{ }^{238} U$ & ${ }^{235} \mathrm{U} /{ }^{238} \mathrm{U}$ \\
\hline F1 & $29.9 \pm 1.9$ & $0.60 \pm 0.10$ & $3.18 \pm 0.34$ & $1.92 \pm 0.26$ & $0.050 \pm 0.050$ & $2.43 \pm 0.31$ & 1.27 & 0.03 \\
\hline $\mathrm{F} 2$ & $18.3 \pm 1.4$ & $0.080 \pm 0.010$ & $0.290 \pm 0.030$ & $0.280 \pm 0.040$ & $0.010 \pm 0.010$ & $0.370 \pm 0.050$ & 1.30 & 0.05 \\
\hline F3 & $38.2 \pm 2.7$ & $0.160 \pm 0.040$ & $1.95 \pm 0.16$ & $1.87 \pm 0.32$ & $0.17 \pm 0.10$ & $2.37 \pm 0.36$ & 1.27 & 0.09 \\
\hline $\mathrm{F} 4$ & $0.960 \pm 0.050$ & $0.210 \pm 0.040$ & $0.510 \pm 0.060$ & $0.380 \pm 0.050$ & - & $0.670 \pm 0.070$ & 1.75 & 0.00 \\
\hline F5 & $14.42 \pm 0.55$ & $0.140 \pm 0.020$ & $0.490 \pm 0.050$ & $0.400 \pm 0.050$ & - & $0.570 \pm 0.060$ & 1.42 & 0.00 \\
\hline L1 & $351 \pm 33$ & $9.2 \pm 2.1$ & $10.9 \pm 2.2$ & $0.64 \pm 0.36$ & $2.6 \pm 1.7$ & $5.7 \pm 2.1$ & 8.89 & 4.00 \\
\hline L2 & $166.4 \pm 5.5$ & $0.380 \pm 0.080$ & $2.60 \pm 0.23$ & $7.88 \pm 0.46$ & $0.98 \pm 0.15$ & $7.73 \pm 0.45$ & 0.98 & 0.12 \\
\hline L3 & $145 \pm 11$ & $0.280 \pm 0.070$ & $0.249 \pm 0.079$ & $0.660 \pm 0.080$ & - & $0.87 \pm 0.10$ & 1.32 & 0.00 \\
\hline L4 & $617 \pm 50$ & $0.95 \pm 0.52$ & $1.09 \pm 0.53$ & $0.52 \pm 0.13$ & $0.010 \pm 0.020$ & $0.300 \pm 0.090$ & 0.57 & 0.03 \\
\hline L5 & $307 \pm 12$ & $0.29 \pm 0.12$ & $0.95 \pm 0.25$ & $1.22 \pm 0.11$ & $0.050 \pm 0.020$ & $1.35 \pm 0.12$ & 1.10 & 0.04 \\
\hline L6 & $182.8 \pm 4.9$ & - & - & $3.60 \pm 0.58$ & $2.97 \pm 0.29$ & $4.78 \pm 0.58$ & 1.33 & 0.83 \\
\hline L7 & $120 \pm 4$ & $5.94 \pm 0.22$ & $6.74 \pm 0.25$ & $2.93 \pm 0.11$ & $0.140 \pm 0.020$ & $4.67 \pm 0.15$ & 1.60 & 0.05 \\
\hline L8 & $135.1 \pm 3.9$ & $0.590 \pm 0.050$ & $1.169 \pm 0.089$ & $1.62 \pm 0.10$ & $0.030 \pm 0.010$ & $1.95 \pm 0.11$ & 1.20 & 0.02 \\
\hline L9 & $275 \pm 8$ & $2.5 \pm 1.2$ & $3.5 \pm 1.5$ & $3.36 \pm 0.33$ & $0.190 \pm 0.080$ & $5.08 \pm 0.41$ & 1.51 & 0.06 \\
\hline L10 & $358 \pm 23$ & $1.23 \pm 0.12$ & $2.36 \pm 0.17$ & $3.57 \pm 0.89$ & $0.28 \pm 0.29$ & $4.7 \pm 1.1$ & 1.32 & 0.08 \\
\hline L11 & $303.5 \pm 3.1$ & $3.07 \pm 0.16$ & $29.4 \pm 1.2$ & $56.0 \pm 1.4$ & $1.96 \pm 0.12$ & $54.0 \pm 1.3$ & 0.96 & 0.04 \\
\hline L12 & $213.5 \pm 8.5$ & $1.17 \pm 0.12$ & $3.73 \pm 0.24$ & $0.330 \pm 0.060$ & $0.010 \pm 0.010$ & $0.350 \pm 0.060$ & 1.04 & 0.02 \\
\hline M1 & $257 \pm 6$ & $1.390 \pm 0.090$ & $23.62 \pm 0.99$ & $270.6 \pm 6.7$ & $22.18 \pm 0.63$ & $249.7 \pm 6.2$ & 0.92 & 0.08 \\
\hline M2 & $721 \pm 16$ & $4.90 \pm 0.22$ & $28.7 \pm 1.1$ & $22.30 \pm 0.61$ & $0.410 \pm 0.050$ & $34.74 \pm 0.88$ & 1.56 & 0.02 \\
\hline M3 & $107.2 \pm 3.3$ & $6.18 \pm 0.31$ & $6.69 \pm 0.33$ & $3.84 \pm 0.19$ & $0.790 \pm 0.070$ & $6.97 \pm 0.29$ & 1.82 & 0.21 \\
\hline M4 & $150.0 \pm 4.1$ & $4.05 \pm 0.23$ & $5.77 \pm 0.30$ & $20.61 \pm 0.76$ & $0.720 \pm 0.080$ & $24.99 \pm 0.88$ & 1.21 & 0.04 \\
\hline
\end{tabular}

Analytical uncertainties corresponding to $1 \sigma$ standard deviation.

Table 4

Radionuclides content in coal, coal ash and soil samples.

\begin{tabular}{|c|c|c|c|c|c|c|c|c|}
\hline Sample & ${ }^{210} \mathrm{Po}\left(\mathrm{Bqkg}^{-1}\right)$ & ${ }^{232} \mathrm{Th}\left(\mathrm{Bqkg}^{-1}\right)$ & ${ }^{230} \mathrm{Th}\left(\mathrm{Bqkg}^{-1}\right)$ & ${ }^{238} \mathrm{U}\left(\mathrm{Bqkg}^{-1}\right)$ & ${ }^{235} \mathrm{U}\left(\mathrm{Bqkg}^{-1}\right)$ & ${ }^{234} \mathrm{U}\left(\mathrm{Bqkg}^{-1}\right)$ & ${ }^{234} U /{ }^{238} U$ & ${ }^{235} \mathrm{U} /{ }^{238} \mathrm{U}$ \\
\hline A1 & $875 \pm 29$ & $17.3 \pm 1.6$ & $474 \pm 25$ & $1167 \pm 27$ & $40.3 \pm 1.9$ & $1099 \pm 25$ & 0.94 & 0.03 \\
\hline $\mathrm{A} 2$ & $891 \pm 29$ & $16.2 \pm 1.1$ & $450 \pm 18$ & $651 \pm 20$ & $21.9 \pm 1.6$ & $698 \pm 22$ & 1.07 & 0.03 \\
\hline $\mathrm{C} 1$ & $352 \pm 21$ & $19.2 \pm 1.2$ & $16.80 \pm 0.98$ & $822 \pm 24$ & - & $802 \pm 23$ & 0.98 & - \\
\hline $\mathrm{C} 2$ & $234.7 \pm 7.8$ & $3.47 \pm 0.49$ & $86.9 \pm 4.4$ & $223.6 \pm 6.4$ & $11.00 \pm 0.92$ & $181.9 \pm 5.4$ & 0.81 & 0.05 \\
\hline S1 & $70.1 \pm 3.7$ & $22.1 \pm 1.2$ & $18.2 \pm 1.0$ & $22.8 \pm 1.3$ & $1.19 \pm 0.27$ & $27.4 \pm 1.4$ & 1.20 & 0.05 \\
\hline S2 & $81.7 \pm 4.1$ & $20.3 \pm 1.6$ & $28.2 \pm 1.5$ & $40.1 \pm 1.8$ & $2.27 \pm 0.38$ & $45.0 \pm 1.9$ & 1.12 & 0.06 \\
\hline S3 & $142.9 \pm 4.6$ & $28.38 \pm 0.97$ & $63.6 \pm 1.9$ & $23.4 \pm 1.3$ & $1.22 \pm 0.28$ & $28.1 \pm 1.4$ & 1.20 & 0.05 \\
\hline
\end{tabular}

Analytical uncertainties corresponding to $1 \sigma$ standard deviation.

Table 5

Average activity concentrations for radionuclides in mosses, lichens and ferns samples $\left(\mathrm{Bqkg}^{-1}\right)$.

\begin{tabular}{llll}
\hline & Mosses & Lichens & Ferns \\
\hline${ }^{210} \mathrm{Po}$ & $308.8 \pm 7.4$ & $264 \pm 15$ & $25.2 \pm 1.7$ \\
${ }^{230} \mathrm{Th}$ & $16.18 \pm 0.68$ & $5.69 \pm 0.61$ & $1.28 \pm 0.13$ \\
${ }^{232} \mathrm{Th}$ & $4.13 \pm 0.21$ & $2.33 \pm 0.43$ & $0.230 \pm 0.050$ \\
${ }^{238} \mathrm{U}$ & $79.3 \pm 2.1$ & $6.86 \pm 0.38$ & $0.97 \pm 0.15$ \\
${ }^{235} \mathrm{U}$ & $6.03 \pm 0.21$ & $0.77 \pm 0.23$ & $0.050 \pm 0.050$ \\
${ }^{234} \mathrm{U}$ & $79.1 \pm 2.1$ & $7.63 \pm 0.54$ & $1.28 \pm 0.17$ \\
\hline
\end{tabular}

Analytical uncertainties corresponding to $1 \sigma$ standard deviation.

and has a single attachment to the surface, its species are different from lichens classified as foliose (samples L1 and L4-L12) and are known to have the largest ratio of surface area to dry weight, having thalli with surfaces well attached to the substrate (Käffer et al., 2012). Crustose lichens seem to be more resistant than other groups, while the fruticose group appears to be the most sensitive and the foliose group has some sensitivity, resisting more than the fruticose species. This illustrates how in the area human activities coal mining and coal-fired power plant are capable to affect the lichen community. Such is comparable to results recorded by Käffer et al. (2011) at Porto Alegre city, Rio Grande do Sul State, southern Brazil, where the crustose lichens were the most abundant group, followed by the foliose type. This also indicates that the species sampled are representative of the investigated area.

Some studies have indicated that foliose lichens accumulate a larger amount of elements than the fruticose (St. Clair et al., 2002).
In the study area, fruticose lichens (L2 and L3) exhibited lower ${ }^{210} \mathrm{Po}$ activity concentration than the foliose lichens L1, L4 and L5 sampled in the same site.

The lichens community is not so diverse in anthropic areas as in wilderness. The species tolerate the excess of light and wind like the Parmeliaceae family (Käffer et al., 2011), represented in the study area by samples L1, L3-L6, L8-L12. Some specimens of Ramalinaceae (L2) and Physciaceae (L7) were also sampled in this study. Käffer et al. (2011) found a predominance of Parmeliaceae and Physciaceae families in the urban area of Porto Alegre city, while Parmotrema, Heterodermia, Hypotrachyna and Canoparmelia were characterized in all areas. Such distribution agrees with the materials sampled at Figueira city and by Martins et al. (2008). Following the Parmeliaceae family, Physciaceae is the second most abundant family in number of species in Brazil (Marcelli, 1998).

In general, mosses species seem to accumulate more ${ }^{210}$ Po than lichens species. The specie Cylindrocolea rhizantha (Mont.) R.M. Schust (M1 and M2) exhibited 2-8 times higher ${ }^{210} \mathrm{Po}$ activity concentration than Sematophyllum galipense (Müll. Hal.) Mit (M3 and M4). Differences were found in the radionuclides absorption due to biological characteristics of the mosses species and also due to environmental factors. For example, M3 and M4 were sampled in more elevated areas than M1 and M2 but in upstream areas from the thermal power plant and coal mine according to the wind preferential direction. Delfanti et al. (1999) reported that high trace metals concentration in mosses is found in the thickest and densest organisms and on the hills exposed to the prevailing winds and to higher rainfall. Sematophyllum galipense (Müll. Hal.) Mit has larger 
phyllodes than Cylindrocolea rhizantha (Mont.) R.M. Schust but seems to accumulate less polonium. This specie also exhibited lower activity concentrations of ${ }^{230} \mathrm{Th},{ }^{238} \mathrm{U}$ and ${ }^{234} \mathrm{U}$.

The contact between the moss and its substrate is not very well developed (Boryło et al., 2012), thus, they usually acquire the essential minerals throughout its surface exposed to the atmosphere. Despite this, vegetation living on basalt substrate has a considerable potential to accumulate trace elements in their tissues, like mosses and lichens that are capable to absorb elements from the rocky material (Bao et al., 2016). In the study area it was not found any correlation between the activity concentration of the radionuclides and the type of substrate on which all the samples were collected. But the species Cylindrocolea rhizantha (Mont.) R. M. Schust showed higher activity concentration of the uranium isotopes in soil (M1) than in rock (M2) as substratum. Contrarily, the activity concentration for ${ }^{210} \mathrm{Po}$ and thorium isotopes in $\mathrm{M} 2$ was higher in the rock as substratum.

Besides the biological features, environmental characteristics also modify the absorption of elements by lichens and mosses and the type of vegetation covering the sampling points is other important factor that may control the ${ }^{210}$ Po activity concentration in mosses (and also in lichens) because of the species, that grow in lower parts of tree trunks, are protected from direct radioactive deposition (Sert et al., 2011). The vegetation in the area didn't affect in a significant way the radionuclides absorption by the biomonitors, once the lichens samples L1, L4 and L10 showed the highest ${ }^{210} \mathrm{Po}$ activity concentration and are placed in areas covered by forest on the banks of Laranjinha river and Pedras stream (Fig. 2).

On the other hand, rock without covering vegetation was the substratum for samples L6 and L7 that exhibited the lowest ${ }^{210} \mathrm{Po}$ activity concentration together with the fruticose species L8, L2 and L3. This could be linked to the preferred wind direction as indicated in Figs. 4-6, that show the ${ }^{210} \mathrm{Po},{ }^{232} \mathrm{Th},{ }^{230} \mathrm{Th},{ }^{238} \mathrm{U},{ }^{235} \mathrm{U}$ and ${ }^{234} \mathrm{U}$ activity concentration content in ferns, mosses and lichens samples (the pie chart express the relative values for each radionuclide).

The prevailing wind direction in the area (SE-NW) agrees with some radionuclides activity concentrations in lichen samples (Fig. 6). Sample L4 exhibited the highest ${ }^{210}$ Po level, L1 showed the highest activity concentration of ${ }^{232} \mathrm{Th}$ and ${ }^{230} \mathrm{Th}$ and $\mathrm{L} 2$ showed the highest ${ }^{238} \mathrm{U}$ level. These samples are in an area of lower elevation, exhibiting high ${ }^{210}$ Po activity concentration although they are surrounded by a topographic elevation and located in a distant area from the emission point. However, samples L12 and L6L8 were located upstream the thermal power plant according to the preferential wind direction and exhibited lower ${ }^{210}$ Po activity concentration. Sample F1 was located in a distant area from the thermal power plant but showed the highest activity concentrations of ${ }^{232} \mathrm{Th},{ }^{230} \mathrm{Th},{ }^{238} \mathrm{U}$ and ${ }^{234} \mathrm{U}$ in comparison to other ferns samples.

Sert et al. (2011) investigated the distance of a thermal power plant and the contamination in mosses and lichens, concluding that the prevailing wind direction is crucial in determining the main deposition points of the elements. They also reported a decrease in the pollutants concentration with the distance increase from the

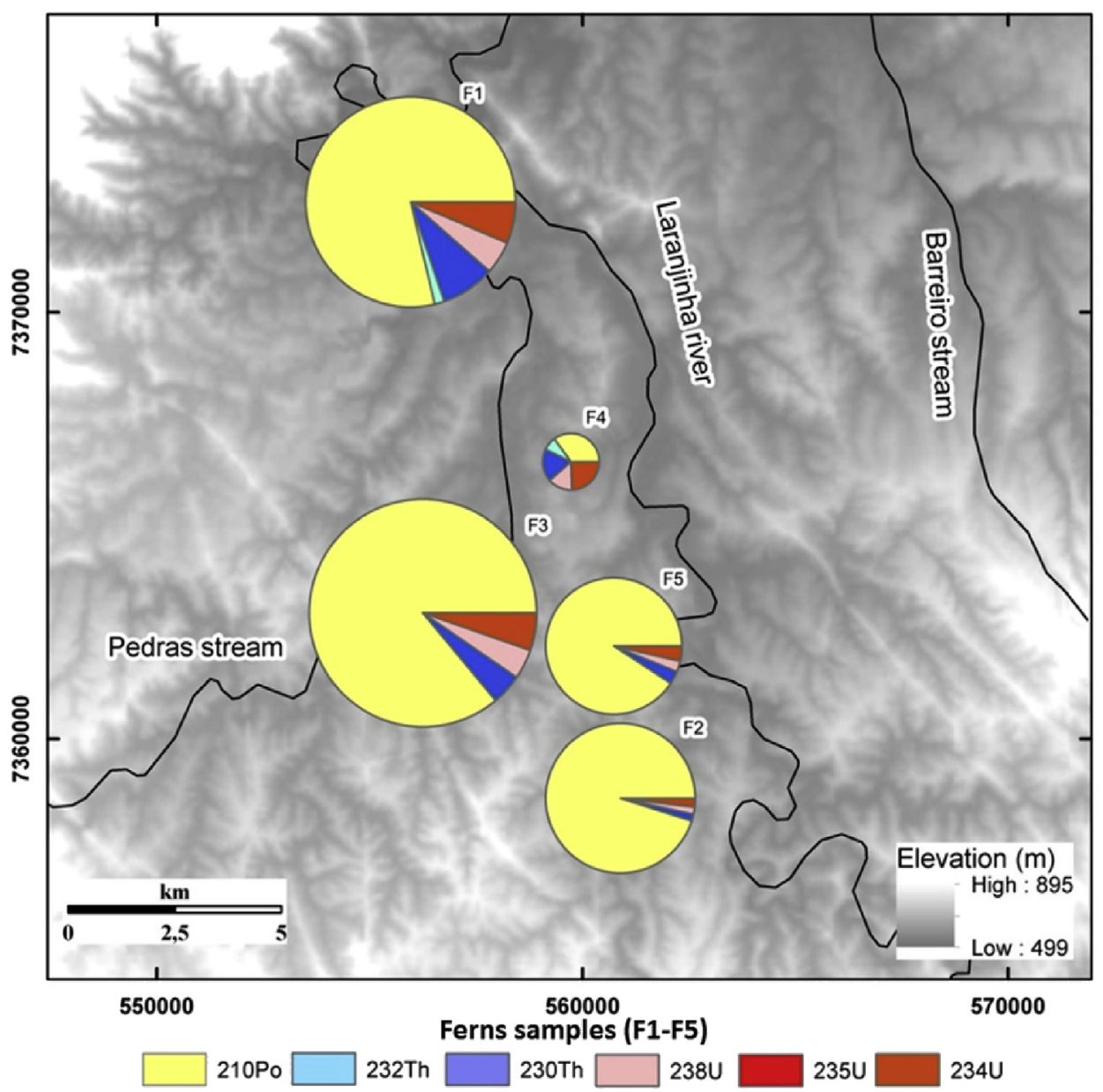

Fig. 4. The relative activity concentration of the radionuclides in the ferns samples. 


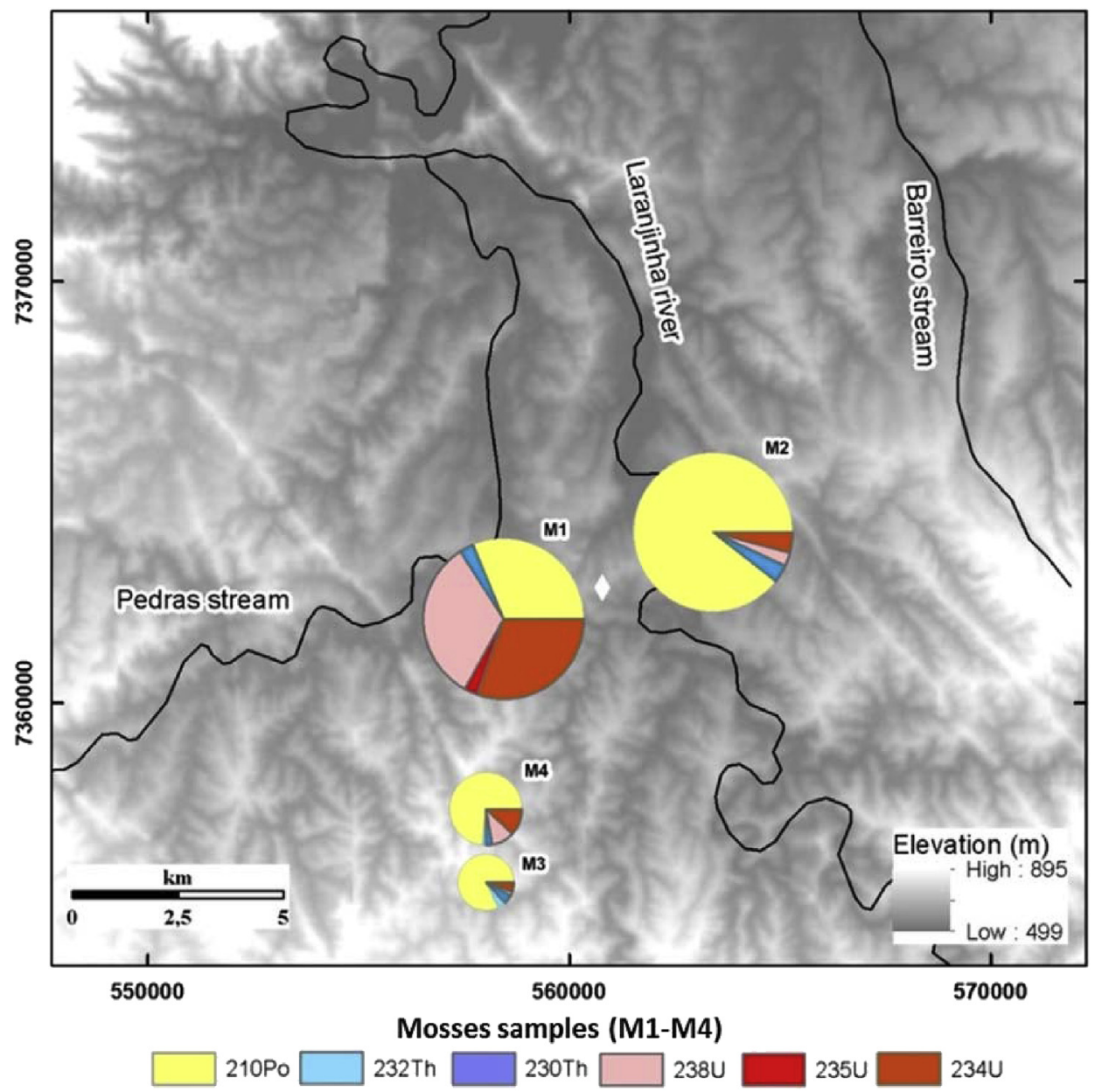

Fig. 5. The relative activity concentration of the radionuclides in the mosses samples.

source of origin. Although the concentrations of radionuclides in lichens and mosses are expected to be inversely correlated with the distance from pollution sources, this relation was not clear in the study area (Figs. 4-6). Detailed mechanisms of the control of substances uptake by lichen have still to be clearly elucidated (Haucka et al., 2013).

Lichens showed high variability of ${ }^{238} \mathrm{U}$ activity concentration, which can be attributed to several factors, such as different background values at the sampling points, different contamination levels in each sampling site, different exposure of the species resulting from the position in which they are located (Loppi et al., 2003) and different bio-accumulation mechanisms (Di Lella et al., 2003).

Fig. 7 ilustrates the relationships among ${ }^{210} \mathrm{Po}$ and ${ }^{238} \mathrm{U}$ for the three groups of samples. In ferns, a significant correlation was found between ${ }^{210} \mathrm{Po}$ and ${ }^{238} \mathrm{U}$ (Pearson's correlation coefficient $r=0.85$, significance level $=0.05$ ), perhaps indicating that besides natural uranium present in the geological materials in the area, the main ${ }^{210}$ Po source for the organisms could be the human activities related to atmospheric particulate matter from the coal combustion. It may contain high amounts of radionuclides, as well as ${ }^{210} \mathrm{~Pb}$ and ${ }^{222} \mathrm{Rn}$ decaying in situ due to their transport through the gaseous emissions.

The natural composition of uranium isotopes in secular equilibrium, i.e, if there is no isotopic fractionation, is characterized by ${ }^{234} \mathrm{U} /{ }^{238} \mathrm{U}$ and ${ }^{235} \mathrm{U} /{ }^{238} \mathrm{U}$ activity ratios of 1.00 and 0.05 , respectively (Jia et al., 2005). The ${ }^{234} \mathrm{U} /{ }^{238} \mathrm{U}$ ratios were $1.27-1.75$ in ferns, $0.92-1.82$ in mosses and $0.57-1.60$ in lichens (disregarding the value of 8.89 in sample L1). These values were generally higher than those found in ashes (0.94-1.07) (Table 3), suggesting additional sources to the particulate material emitted from the coalfired thermal power plant.

Table 6 shows some examples of average radionuclides activity concentration in lichens and mosses around the word. In Brazil, only a few studies have been carried out using biomonitors for the air quality evaluation in terms of radionuclides. The highest levels of ${ }^{210} \mathrm{Po}$ and uranium and thorium isotopes were found in mosses (Jia et al., 2005; Sert et al., 2011 in Table 6) like in the study area. The species of mosses and lichens sampled in regions of coal-fired thermal power plant in other areas (Ugur et al., 2004; Sert et al., 2011 ) exhibited higher mean ${ }^{210}$ Po activity concentrations than in Figueira city. In an area of military conflict, Jia et al. (2005) found average activity concentrations of U-isotopes significantly lower than those found in Figueira city and, in the case of the lichens species, the order of the highest values was the same as found here, i.e. ${ }^{234} \mathrm{U}$ followed by ${ }^{238} \mathrm{U}$ and ${ }^{235} \mathrm{U}$.

The specie Canoparmelia Texana in the study area (sample L11) showed considerably lower levels of ${ }^{238} \mathrm{U}$ and ${ }^{232} \mathrm{Th}$ than in a lead industry area in Brazil (Leonardo et al., 2011). So far, it is concluded that radionuclides accumulation in lichens and mosses is dependent of the specie investigated, also of the source and availability of the radionuclides, the substratum characteristics, the temperature, moisture and other environmental factors.

According to Conti and Cecchetti (2001), biomonitors must accumulate the pollutants without be killed by the levels which they come into contact, have a wide geographical distribution, be 


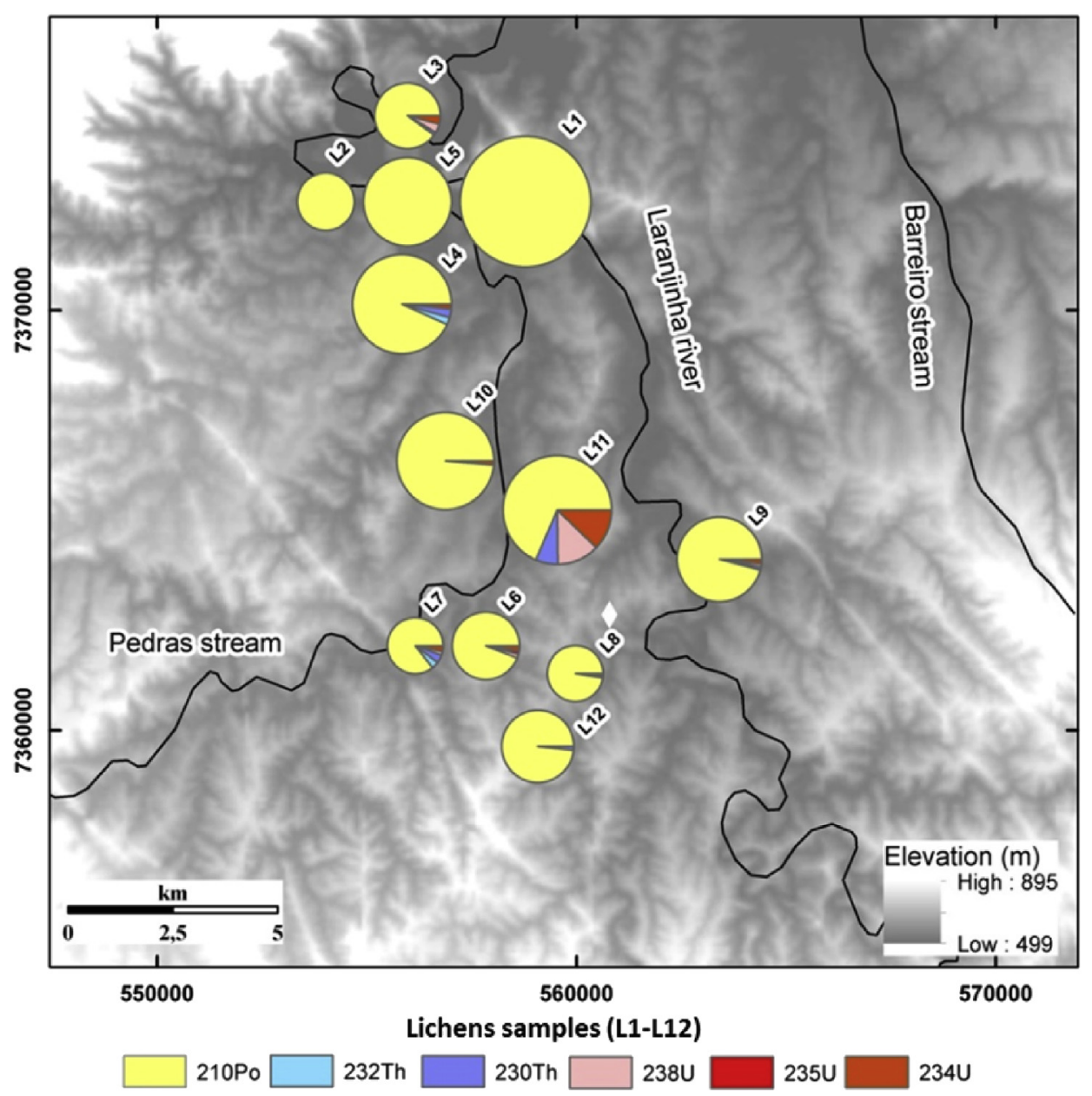

Fig. 6. The relative activity concentration of the radionuclides in the lichens samples.
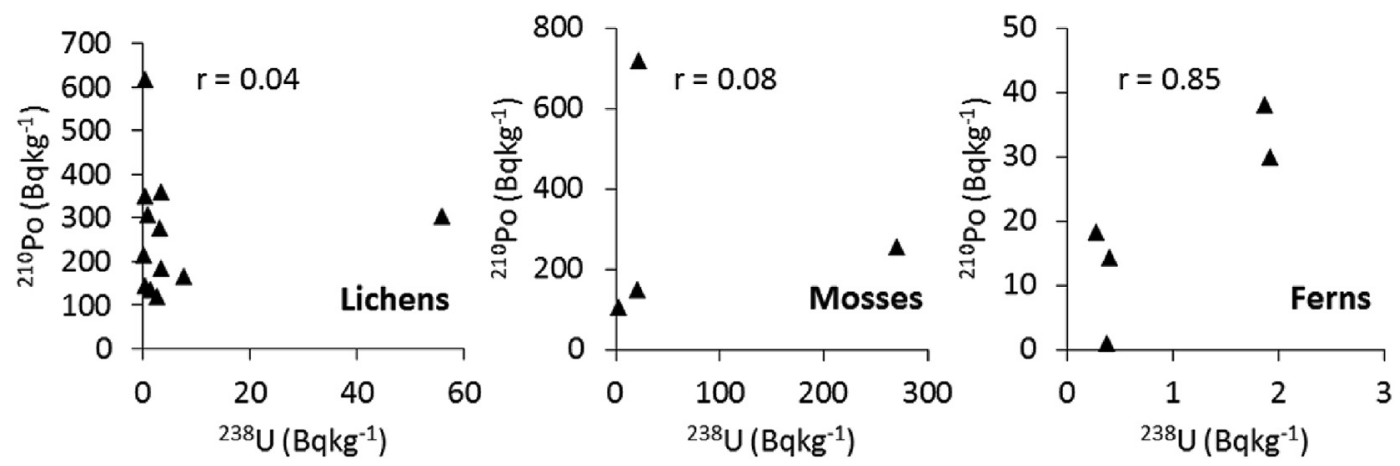

Fig. 7. Relation between ${ }^{238} \mathrm{U}$ and ${ }^{210} \mathrm{Po}$ for the biomonitors groups.

abundant and representative of the area and easy to be sampled, have a high concentration factor for the contaminant under study and have a good correlation between the level of contaminant in the sample and in the surrounding environment. Based on the results obtained, the species of mosses and lichens collected can be used as biomonitors in areas of coal mining and burning to electricity generation in thermal power plants.

\section{Conclusions}

The results obtained through the bio-monitoring are comparable to those found in other regions, confirming the effectiveness of lichens and mosses as bio-monitors of the air quality in coal mine areas from Brazil, where the greatest coal deposits are located in the southern of the country. Thus, they can be used for assessing the environmental damage to the biota caused by coal mining activities and thermal power plants operation. Their use can provide information about the pollutants concentration in atmosphere, in addition to the pollution effects in the environment, also elucidating the ecological consequences of the air pollution especially in southern Brazil, where important industrial, mining and agricultural activities take place, being responsible by the release 
Table 6

Average activity concentration of radionuclides in lichens and mosses.

\begin{tabular}{|c|c|c|c|c|}
\hline Species & Radionuclide & Activity concentration $\left(\mathrm{Bqkg}^{-1}\right)$ & Site & Reference \\
\hline Pleurozium schreberi (moss) & $\begin{array}{l}{ }^{210} \mathrm{Po} \\
{ }^{238} \mathrm{U}\end{array}$ & $\begin{array}{l}318.8 \\
1.62\end{array}$ & Phosphogypsum waste & Boryło et al. (2012) \\
\hline Dicranum scoparium (moss) & $\begin{array}{l}{ }^{210} \mathrm{Po} \\
{ }^{238} \mathrm{U}\end{array}$ & $\begin{array}{l}154.6 \\
2.06\end{array}$ & Heap, Poland & \\
\hline $\begin{array}{l}\text { Lichens species } \\
\text { Mosses species }\end{array}$ & $\begin{array}{l}{ }^{210} \mathrm{Po} \\
{ }^{210} \mathrm{Po}\end{array}$ & $\begin{array}{l}365.00 \\
620.00\end{array}$ & Uraniferous coal-fired power plant, Turkey & Ugur et al. (2004) \\
\hline Lichens species & $\begin{array}{l}{ }^{238} \mathrm{U} \\
{ }^{235} \mathrm{U} \\
{ }^{234} \mathrm{U}\end{array}$ & $\begin{array}{l}2.56 \\
0.30 \\
2.59\end{array}$ & Serbia and Montenegro & Jia et al. (2005) \\
\hline Mosses species & $\begin{array}{l}{ }^{238} \mathrm{U} \\
{ }^{235} \mathrm{U} \\
{ }^{234} \mathrm{U}\end{array}$ & $\begin{array}{l}3.64 \\
0.19 \\
3.68\end{array}$ & & \\
\hline Mosses species & ${ }^{238} \mathrm{U}$ & 43.00 & Belgrade, Serbia & Grdović et al. (2010) \\
\hline $\begin{array}{l}\text { Lichen species } \\
\text { Mosses species }\end{array}$ & $\begin{array}{l}{ }^{210} \mathrm{Po} \\
{ }^{210} \mathrm{Po}\end{array}$ & $\begin{array}{l}400.00 \\
422.57\end{array}$ & $\begin{array}{l}\text { Coal-fired } \\
\text { power plants, Yatagan, Turkey }\end{array}$ & Sert et al. (2011) \\
\hline Canoparmelia texana (lichen) & $\begin{array}{l}{ }^{238} \mathrm{U} \\
{ }^{232} \mathrm{Th}\end{array}$ & $\begin{array}{l}209.51 \\
265.43\end{array}$ & Lead industry, Brazil & Leonardo et al. (2011) \\
\hline
\end{tabular}

into the atmosphere of considerable amounts of radionuclides. The high activity concentration of some radionuclides in mosses and lichens found in this study indicates that human activities associated with the coal mining are capable to modify the air quality, allowing a bio-concentration of radioactive elements on tissues of living organisms, mainly on those species placed in the preferred wind direction. The main advantage associated with the technique of passively bio-monitoring is that it allows obtaining information on the continuous accumulation of radioactive elements integrated over the time which corresponds to the life of an organism and, with the development of analytical methods for extracting elements for analysis, its application becomes more effective for toxic metals and radioactive elements. However, as a few researches took place on tropical environments, where the climatic conditions and also the natural composition of the soils and rocks differ from temperate areas, the comparison between the investigated species and the levels of the radionuclides absorbed by them becomes limited. Mosses seem to be more sensitive, accumulating higher amounts of all investigated radionuclides, followed by lichens. The greater absorption of ${ }^{210} \mathrm{Po}$ by these species may be related to their biological characteristics, but abiotic factors, such as pollution levels, wind direction and climate change may affect the radioelements absorption by mosses. On the other hand, chemically speaking, the specie of fern Microgramma squamulosa (Kaulf.) de la Sota exhibited the same or lower content for all radionuclides investigated than in soils, coal and ash samples, indicating that this specie is less sensitive as a bio-monitor than the mosses and lichens. Since wind velocity, air moisture, rainnfall and other environmental factors can affect the exposure of lichens and mosses to radionuclides and modify their uptake of the radioactive elements, beyond their biological characteristics, it would be recommended a temporal evaluation of their activity concentrations in such biomonitors occurring in southern Brazil.

\section{Acknowledgments}

CNPq (National Council for Scientific and Technologic Development) in Brazil is thanked for financial support of this investigation. Dr. Denilson F. Peralta and Dra. Rosângela Simão-Bianchini, from Botanic Institute of São Paulo, are thanked for the identification of the mosses and ferns species. Two anonymous referees are greatly thanked for helpul comments that improved the readability of the manuscript.

\section{References}

ANEEL (Agência Nacional de Energia Elétrica), 2011. A Situação da Produção de Carvão Mineral no Estado do Paraná em Relação a Nota Técnica 034/2011. Tech. Rep. ANEEL, Brasília.

Alencar, M.M., 2008. Determinação de isótopos de urânio e tório em amostras de liquens Canoparmelia texana. Master's Thesis. Instituto de Pesquisas Espaciais e Nucleares, Universidade de São Paulo, São Paulo.

Alves, E.S., Giusti, P.M., Domingos, M., Saldiva, P.H.N., Guimarães, E.T., Lobo, D.J.A., 2001. Estudo anatômico foliar do clone híbrido de Tradescantia: alterações decorrentes da poluição aérea urbana. Rev. Bras. Bot. 24, 561-566. http:// dx.doi.org/10.1590/S0100-84042001000500012.

Bargagli, R., Brownrown, D.H., Nelli, L., 1995. Metal biomonitoring with mosses: procedures for correcting for soil contamination. Environ. Pollut. 89, 169-175. http://dx.doi.org/10.1016/0269-7491(94)00055-I.

Bao, Y., Ju, Y., Li, B., Sun, Y., 2016. Migration of trace elements from basalt substrate to co-located vegetation (lichens and mosses) at the Wudalianchi volcanos Northeast China. J. Asian Earth Sci. 118, 95-100. http://dx.doi.org/10.1016/ j.jseaes.2015.12.027.

Baxter, M.S., 1993. Environmental radioactivity: a perspective on industrial contributions. IAEA Bull. 35 (2), 33-38.

Beckett, P.J., Boileau, L.J.R., Padovan, D., Richardson, D.H.S., 1982. Lichens and mosses as monitors of industrial activity associated with uranium mining in northern Ontario, Canadá - Part 2: distance dependent uranium and lead accumulations patterns. Environ. Pollut. 4, 91-107. http://dx.doi.org/10.1016/0143-148X(82) 90020-9.

Belivermis, M.E., Çotuk, Y., 2010. Radioactivity measurements in moss (Hypnum cupressiforme) and lichen (Cladonia rangiformis) samples collected from Marmara region of Turkey. J. Environ. Radioact. 101, 945-951. http://dx.doi.org/ 10.1016/j.jenvrad.2010.06.012.

Berg, T., Royset, O., Steinnes, E., 1995. Moss (Hylocomium splendens) used as biomonitor of atmospheric trace element deposition: estimation of uptake efficiencies. Atmos. Environ. 29 (3), 353-360. http://dx.doi.org/10.1016/13522310(94)00259-N.

Boryło, A., Nowicki, W., Olszewski, G., Skwarzec, B., 2012. Polonium ( $\left.{ }^{210} \mathrm{Po}\right)$, Uranium $\left({ }^{234} \mathrm{U},{ }^{238} \mathrm{U}\right)$ isotopes and trace metals in mosses from Sobieszewo Island, northern Poland. J. Environ. Sci. Health 47, 1831-1842. http://dx.doi.org/ 10.1080/10934529.2012.689549.

Büdel, B., Scheidegger, C., 1996. Thallus morphology and anatomy. In: Nash, T.H. (Ed.), Lichen Biology. Cambridge University Press.

Campaner, V.P., Luiz-Silva, W., Machado, W., 2014. Geochemistry of acid mine drainage from a coal mining area and processes controlling metal attenuation in stream waters, southern Brazil. An. Acad. Bras. Ciênc. 86 (2), 539-544. http:// dx.doi.org/10.1590/0001-37652014113712.

Carreras, H.A., Wannaz, E.D., Pignata, M.L., 2009. Assessment of human health risk related to metals by the use of biomonitors in the province of Córdoba Argentina. Environ. Pollut. 157, 117-122. http://dx.doi.org/10.1016/ j.envpol.2008.07.018.

Conti, M.E.E., Cecchetti, G., 2001. Biological monitoring: lichens as bioindicators of air pollution assessment - a review. Environ. Pollut. 114, 471-492. http:// dx.doi.org/10.1016/S0269-7491(00)00224-4.

Delfanti, R., Papucci, C., Benco, C., 1999. Mosses as indicators of radioactivity deposition around a coal-fired power station. Sci. Total Environ. 227, 49-56. http://dx.doi.org/10.1016/S0048-9697(98)00410-0.

Di Lella, L.A., Frati, L., Loppi, S., Protano, G., Riccobono, F., 2003. Lichens as biomonitors of uranium and other trace elements in an area of Kosovo heavily shelled with depleted uranium rounds. Atmos. Environ. 37, 5445-5449. http:// 
dx.doi.org/10.1016/j.atmosenv.2003.09.009.

Dubuisson, J., Schneider, H., Hennequin, S., 2009. Epiphytism in ferns: diversity and history. Comptes Rendus Biol. 332, 120-128. http://dx.doi.org/10.1016/ j.crvi.2008.08.018.

Díaz-Francés, I., Mantero, J., Manjón, G., Díaz, J., García-Tenorio, R., 2013. ${ }^{210}$ Po and ${ }^{238} \mathrm{U}$ isotope concentrations in commercial bottled mineral water samples in Spain and their dose contribution. Radiat. Prot. Dosim. 156 (3), 336-342. http:// dx.doi.org/10.1093/rpd/nct075.

Elias, C., Fernandes, E., De Franca, E.J., Bacchi, M.A., 2006. Seleção de epífitas acumuladoras de elementos químicos na Mata Atlântica. Biota Neotrop. 6, 1-9. http://dx.doi.org/10.1590/S1676-06032006000100010.

Fernandez, J.A., Rey, A., Carballeira, A., 2000. An extended study of heavy metal deposition in Galicia (NW Spain) based on moss analysis. Sci. Total Environ. 254 31-44. http://dx.doi.org/10.1016/S0048-9697(00)00431-9.

Figueira, R., Sergio, C., Sousa, A.J., 2002. Distribution of trace metals in moss biomonitors and assessment of contamination sources in Portugal. Environ. Pollut 118, 153-163. http://dx.doi.org/10.1016/S0269-7491(01)00203-2.

Flues, M., Camargo, I.M.C., Silva, P.S.C., Mazzilli, B.P., 2006. Radioactivity of coal and ashes from Figueira coal power plant in Brazil. J. Radioanal. Nucl. Chem. 270 (3) 597-602. http://dx.doi.org/10.1007/s10967-006-0467-0.

Fungaro, D.A.E., Izidoro, J.C., 2006. Remediação da drenagem ácida de mina usando zeólitas sintetizadas a partir de cinzas leves de carvão. Quim. Nova 29 (4) 735-740. http://dx.doi.org/10.1590/S0100-40422006000400019.

Garty, J., Tomer, S., Levin, T., Lehr, H., 2003. Lichens as biomonitors around a coalfired power station in Israel. Environ. Res. 91, 186-198. http://dx.doi.org 10.1016/S0013-9351(02)00057-9.

Genoni, P., Parco, V., Santagostino, A., 2000. Metal biomonitoring with mosses in the surroundings of an oil-fired power plant in Italy. Chemosphere 41, 729-733. http://dx.doi.org/10.1016/S0045-6535(99)00457-9.

Giblin, A.M., Batts, B.D., Swaine, D.J., 1981. Laboratory simulation studies of uranium mobility in natural waters. Geochim. Cosmochim. Acta 45, 699-709. http:/ dx.doi.org/10.1016/0016-7037(81)90043-0.

Golubev, A.V., Golubeva, V.N., Krilov, N.G., Kusnetsova, V.F., Mavrin, S.V., Aleinikov, A. Yu, Hoppes, W.G., Surano, K.A., 2005. On monitoring antrophogenic airbone uranium concentrations and ${ }^{235} \mathrm{U} /{ }^{238} \mathrm{U}$ isotopic ratio by lichen bioindicator techinic. J. Environ. Radioact. 84, 333-342. http://dx.doi.org/ 10.1016/j.jenvrad.2005.04.002.

Grdović, S., Vitorović, G., Mitrović, B., Petrujkić, A.B., Obradović, M., 2010. Natural and anthropogenic radioactivity of feedstuffs, mosses and soil in the Belgrade environment, Serbia. Arch. Biol. Sci. Belgrade 62 (2), 301-307. http://dx.doi.org 10.2298/ABS1002301G.

Hallstadius, L., 1984. A method for the electrodeposition of actinides. Nucl. Instrum. Methods A 223, 266-267. http://dx.doi.org/10.1016/0167-5087(84)90659-8.

Haucka, M., Böning, J., Jacob, M., Dittrich, S., Feussner, I., Leuschner, C., 2013. Lichen substance concentrations in the lichen Hypogymnia physodes are correlated with heavy metal concentrations in the substratum. Environ. Exp. Bot. 85 58-63. http://dx.doi.org/10.1016/j.envexpbot.2012.08.011.

Heinrich, G., Oswald, K., Müller, H.J., 1999. Lichens as monitors of radiocesium and radiostrontium in Austria. J. Environ. Radioact. 45, 13-27. http://dx.doi.org/ 10.1016/S0265-931X(98)00069-1.

International Atomic Energy Agency (IAEA), 2010. Handbook of Parameter Values for the Prediction of Radionuclide Transfer in Terrestrial and Freshwater Environments. IAEA, Vienna, p. 194

Jeran, Z.E., Jacimovic, R., 2001. The Use of lichens and mosses to monitor trace element and radionuclide pollution in Slovenia. Radionucl. Heavy Met. Environ. 5, 171-178. http://dx.doi.org/10.1007/978-94-010-0993-5_26.

Jia, M.B., Sansone, U., Rosamilia, S., Gaudino, S., 2005. Concentration and characteristics of depleted uranium in water, air and biological samples collected in Serbia and Montenegro Guogang. Appl. Radiat. Isot. 63, 381-399. http:/ dx.doi.org/10.1016/j.apradiso.2005.05.042

Käffer, M.I., Martins, S.M.A., Alves, C., Pereira, V.C., Fachel, J., Vargas, V.M.F., 2011 Corticolous lichens as environmental indicators in urban areas in southern Brazil. Ecol. Indic. 11, 1319-1332. http://dx.doi.org/10.1016/ j.ecolind.2011.02.006.

Käffer, M.I., Lemos, A.T., Apel, M.A., Rocha, J.V., Martins, S.M.A., Vargas, V.M.F., 2012 Use of bioindicators to evaluate air quality and genotoxic compounds in an urban environment in Southern Brazil. Environ. Pollut. 163, 24-31. http:// dx.doi.org/10.1016/j.envpol.2011.12.006.

Kirchner, G.E., Daillant, O., 2002. The potential of lichens as long-term biomonitors of natural and artificial radionuclides. Environ. Pollut. 120, 145-150. http:// dx.doi.org/10.1016/S0269-7491(02)00139-2.

Landa, E.R., 2003. Mobilization of radionuclides from uranium mill tailings and related waste materials in anaerobic environments. J. Radioanal. Nucl. Chem. 255 (3), 559-563.

Leonardo, L., Mazzilli, B.P., Damatto, S.R., Saiki, M., Barros De Oliveira, S.M., 2011 Assessment of atmospheric pollution in the vicinity of a tin and lead industry using lichen species Canoparmelia texana. J. Environ. Radioact. 102, 906-910. http://dx.doi.org/10.1016/j.jenvrad.2010.04.002.

Leonardo, L., Damatto, S.R., Gios, B.R., Mazzilli, B.P., 2013. Lichen specie Canoparmelia texana as bioindicator of environmental impact from the phosphate fertilizer industry of São Paulo, Brazil. J. Radioanal. Nucl. Chem. 299, 1.935-1.941. http://dx.doi.org/10.1007/s10967-013-2887-y.

Lehritani, M., Mantero, J., Casacuberta, N., Masqué, P., García-Tenorio, R., 2012 Comparison of two sequential separation methods for $U$ and Th determination in environmental samples by alpha-particle spectrometry. Radiochim. Acta 100
(7), 431-438. http://dx.doi.org/10.1524/ract.2012.1933.

Loppi, S., Riccobono, F., Zhang, Z.H., Savic, S., Ivanovd, D., Pirintsose, S.A., 2003. Lichens as biomonitors of uranium in the Balkan area. Environ. Pollut. 125 277-280. http://dx.doi.org/10.1016/S0269-7491(03)00057-5.

Mantero, J., Lehritane, M., Hurtado, S., García-Tenorio, R., 2010. Radioanalytical determination of actinides in refractory matrices by alkali fusion. J. Radioanal. Nucl. Chem. 286, 557-563. http://dx.doi.org/10.1007/s10967-010-0782-3.

Markert, B., 2007. Definitions and principles for bioindication and biomonitoring of trace metals in the environment. J. Trace Elem. Med. Biol. 21, 77-82. http:// dx.doi.org/10.1016/j.jtemb.2007.09.015.

Marcelli, M.P., 1998. History and current knowldge of Brazilian lichenology. In: Marcelli, M.P., Seaward, M.R.D. (Eds.), Lichenology in Latin America: History, Current Knowledge and Application. CETESB, São Paulo, pp. 25-45.

Martins, S.M.A., Käffer, M.I., Lemos, A., 2008. Liquens como bioindicadores da qualidade do ar numa área de termoelétrica, Rio Grande do Sul, Brasil. Hoehnea 35 (3), 425-433.

Medeiros, R.A., Thomaz Filho, A., 1973. Fácies e ambientes deposicionais da Formação Rio Bonito. In: XXVII Congresso Brasileiro de Geologia, São Paulo.

Mkandawire, M., 2013. Biogeochemical behaviour and bioremediation of uranium in waters of abandoned mines. Environ. Sci. Pollut. Res. 20, 7740-7767. http:// dx.doi.org/10.1007/s11356-013-1486-3.

Mohlenbrock, R.H., 2006. This Land: a Guide to Eastern National Forests. University of California Press, Berkeley, California, USA.

Nifontova, M., 1995. Radionuclides in the moss-lichen cover of tundra communities in the YamalPeninsula. Sci. Total Environ. 160, 749-752. http://dx.doi.org/ 10.1016/0048-9697(95)04408-S.

Nordstrom, D.K., 2009. Acid rock drainage and climate change. J. Geochem. Explor 100, 97-104. http://dx.doi.org/10.1016/j.gexplo.2008.08.002.

Papastefanou, C., 2010. Escaping radioactivity from coal-fired power plants (CPPs) due to coal burning and the associated hazards: a review. J. Environ. Radioact. 101, 191-200. http://dx.doi.org/10.1016/j.jenvrad.2009.11.006.

Rocha, L.D., Costa, G.M., Gehlen, G., Droste, A., Schmitt, J.L., 2014. Morphometric differences of Microgramma squamulosa (Kaulf.) de la Sota (Polypodiaceae) leaves in environments with distinct atmospheric air quality. An. Acad. Bras. Ciênc 86 (3), 1137-1146. http://dx.doi.org/10.1590/0001-3765201420130094.

Saiki, M., Alves, E.R., Marcelli, M.P., 2007. Analysis of lichen species for atmospheric pollution biomonitoring in the Santo André Municipaty. J. Radional. Nucl. Chem. 273 (3), 543-547. http://dx.doi.org/10.1007/s10967-007-0906-6.

Seed, L., Wolseley, P., Gosling, L., Davies, L., Sally, A., 2013. Power. Modelling relationships between lichen bioindicators, air quality and climate on a national scale: results from the UK OPAL air survey. Environ. Pollut. 182, 437-447. http:// dx.doi.org/10.1016/j.envpol.2013.07.045.

Sert, E., Ugur, A., Özden, B., Saç, M.M., Camgöz, B.C., 2011. Biomonitoring of 210Po and $210 \mathrm{~Pb}$ using lichens and mosses around coal-fired power plants in Western Turkey. J. Environ. Radioact. 102, 535-542. http://dx.doi.org/10.1016/S13522310(03)00147-X.

Shuqair, M.S.S., 2002. Estudo da contaminação do solo e água subterrânea por elementos tóxicos originados dos rejeitos das minas de carvão de Figueira no Estado do Paraná. PhD Thesis. Universidade de São Paulo, São Paulo.

St Clair, S.B., Clair, L.L., Weber, D.J., Mangelson, N.F., Eggett, D.L., 2002. Element accumulation patterns in foliose and fruticose lichens from rock and bark substrates in Arizona. Bryologist 105 (3), 415-421. http://www.jstor.org/stable/ 3244695.

Steinnes, E.E., Njastad, O., 1993. Use of mosses and lichens for regional mapping of ${ }^{137}$ Cs fallout from the Chernobyl Accident. J. Environ. Radioact. 21, 65-73. http://dx.doi.org/10.1016/0265-931X(93)90026-4.

Steinnes, E., 1995. A critical evaluation of the use of naturally growing moss to monitor the deposition of atmospheric metals. Sci. Total Environ. 160, 243-249. http://dx.doi.org/10.1016/0048-9697(95)04360-D.

Tsikritzis, L.I., Ganatsios, S.S., Duliu, O.G., Sawidis, T.S., 2003. Natural and artificial radionuclides distribution in some lichens, mosses, and trees in the vicinity of lignite power plants from west Macedonia, Greece. J. Trace Microprobe Tech. 21 (3), 543-554. http://dx.doi.org/10.1081/TMA-120023070.

Ugur, A., Özden, B., Saç, M.M., Yener, G., Altinbas, Ü., Kurucu, Y., Bolca, M., 2004. Lichens and mosses for correlation between trace elements and 210Po in the areas near coal-fired power plant at Yataan, Turkey. J. Radioanal. Nucl. Chem. 259, 87-92. http://dx.doi.org/10.1023/B:JRNC.0000015811.68036.69.

UNSCEAR (United Nations Scientific Committee on the Effects of Atomic Radiations), 2010. Sources and Effects of Ionizing Radiations. UNSCEAR, New York. http://www.unscear.org.

USEPA (United States Environmental Protection Agency), 1995. Human Health and Environmental Damages from Mining and Mineral Processing Wastes. Archive document. Office of Solid Waste. US Environ. Protection Agency.

Van Der Wat, E.L., Forbes, P.B.C., 2015. Lichens as biomonitors for organic air pollutants. Trends Anal. Chem. 64, 65-172. http://dx.doi.org/10.1016/ j.trac.2014.09.006.

Villarouco, F.M.O., Freira, E.V.C., Pereira, E.C.G., Pérez, R.E.U., 2007. Análise do líquen Cladonia verticillares (Raddi) Fr., em condições de laboratório sob efeito do estireno e ciclohexano. Interciência 32 (4), 242-246. http://www.scielo.org.ve/ scielo.php?script $=$ sci arttext\&pid $=$ S0378$18442007000400007 \& \operatorname{lng}=$ es\&nrm=iso.

Zhang, Y., Shi, M., Wang, J., Yao, J., Cao, Y., Romero, C.E., Pan, W., 2016. Occurrence of uranium in Chinese coals and its emissions from coal-fired power plants. Fuel 166, 404-409. http://dx.doi.org/10.1016/j.fuel.2015.11.014. 